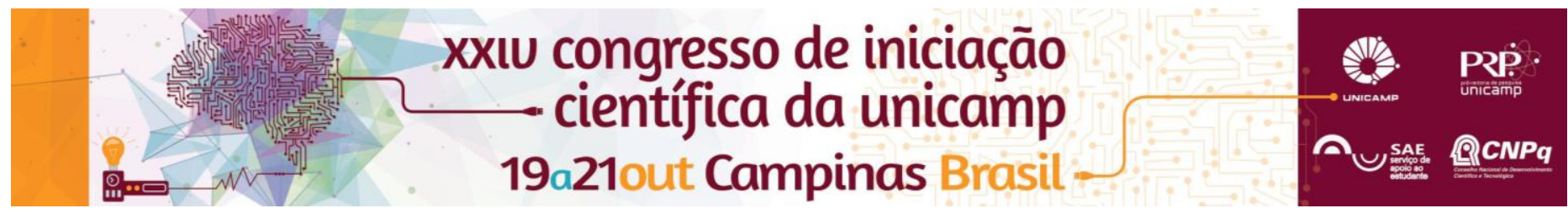

\title{
ANÁLISE MOLECULAR DO GENE NPHS1 EM 19 CRIANÇAS E ADOLESCENTES COM SÍNDROME NEFRÓTICA
}

\author{
Suéllen R. de Souza* (SAE), Mara S. Guaragna (PQ), Maricilda P. de Mello (PQ)
}

\section{Resumo}

A Síndrome Nefrótica (SN) é uma das principais doenças renais na infância, podendo levar à insuficiência renal crônica e ao óbito. Três genes principais (NPHS2, NPHS1 e WT1) são responsáveis por aproximadamente $65 \%$ dos casos de origem genética da SN em crianças. O objetivo deste estudo foi a triagem molecular do gene NPHS1 de 19 pacientes com SN em crianças e adolescentes.

Palavras-chave: Síndrome Nefrótica em crianças e adolescentes, análise molecular, NPHS1.

\section{Introdução}

A Síndrome Nefrótica (SN), uma das principais doenças renais na infância, é definida pelos sintomas proteinúria maciça, edema, hipoalbuminemia e, geralmente, hiperlipidemia. A SN se classifica de acordo com a idade em que se apresenta ou com a resposta ao tratamento'. A doença ocorre devido à disfunção da barreira de filtração glomerular (BFG), resultando na perda de proteínas pela urina. Mutações em aproximadamente 30 genes que codificam para proteínas expressas na BFG vêm sendo descritas nos últimos 15 anos. Três genes principais (NPHS2, NPHS1 e WT1) são responsáveis por aproximadamente $65 \%$ dos casos de origem genética da $\mathrm{SN}$ em crianças. O objetivo deste estudo foi a triagem molecular do gene NPHS1, que codifica a nefrina, em 19 pacientes com SN na infância e juvenil (de 1 ano a 18 anos de idade) para os quais já haviam sido excluídas mutações nos genes NPHS2 e éxons 8-9 do WT1.

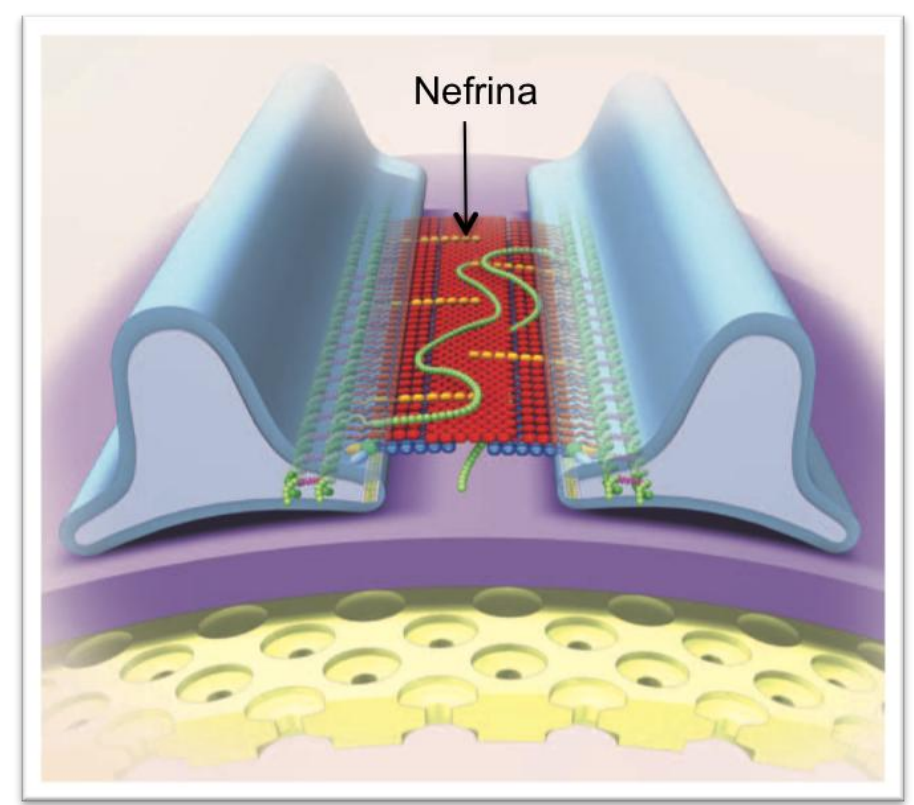

Figura 1. llustração da barreira de filtração glomerular. Observa-se a proteína nefrina em vermelho, principal proteína que interconecta os pedicelos dos podócitos nos diafragmas de fenda.

\section{Resultados e Discussão}

Após extração do DNA pelo método de fenol clorofórmio, os 29 éxons, região promotora e regiões limítrofes éxon/íntron do gene NPHS1 foram amplificados pela reação em cadeia da polimerase (PCR) e sequenciados pelo método Sanger. Após análise das sequências e comparação com o banco de dados (ENST00000378910, www.ensembl.org) identificamos algumas variantes, apresentadas na tabela I. Os resultados ainda são parciais, nem todos os éxons foram analisados em todos os pacientes. As variantes identificadas já foram descritas como não causadoras da doença e são frequentes na população em geral $(M A F>0.05)$. A avaliação molecular da SN é importante pois o estudo genético desta doença ainda é incipiente no Brasil; ainda, em pacientes portadores de mutações pode ser considerado o transplante renal a partir de doador vivo, já que estes apresentam risco menor de recidiva da doença após transplante do que pacientes sem mutações.

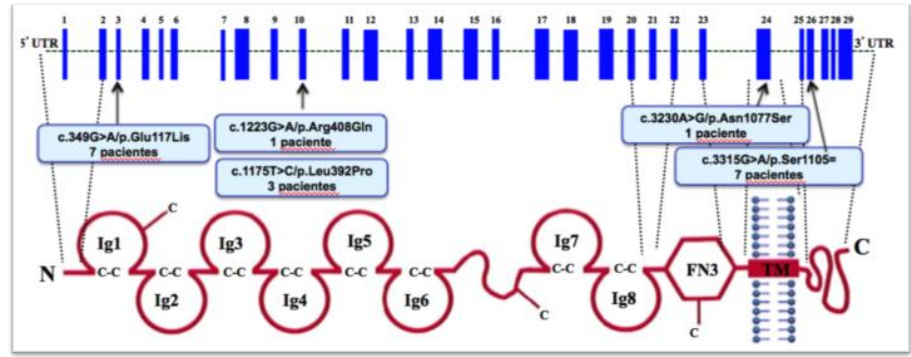

Figura 2: llustração dos 29 éxons do gene NPHS1 (acima, azul) e dos respectivos domínios da proteína nefrina (abaixo, vermelho) por eles codificados. As caixas em azul claro ilustram as variantes identificadas nos pacientes analisados.

\section{Conclusões}

Após análise parcial de parte dos éxons do gene NPHS1 nos 19 pacientes com SN não foi identificada nenhuma variante causadora da doença.

\section{Agradecimentos}

Agradecimentos ao CBMEG, à FAPESP, SAE e ao CNPq.

${ }^{1}$ Benoit G, Machuca E, Antignac C: Hereditary nephrotic syndrome: a systematic approach for genetic testing and a review of associated podocyte gene mutations. Pediatr Nephrol 2010 Sep;25:1621-32. 